\title{
Effect of leptin on ACTH-stimulated secretion of cortisol in rhesus macaques and on human adrenal carcinoma cells
}

\author{
Joaquin Lado-Abeal, James J Mrotek ${ }^{1}$, Douglas M Stocco and Reid L Norman \\ Cell Biology and Biochemistry, Texas Tech University Health Sciences Center, Lubbock, Texas 79430, USA and ${ }^{1}$ Anatomy and Physiology, \\ Meharry Medical College, Nashville, Tennessee 37208, USA
}

(Correspondence should be addressed to R L Norman, Cell Biology and Biochemistry, Texas Tech University Health Sciences Center, 36014 th Street, Lubbock, Texas 79430, USA; Email: reid.norman@ttmc.ttuhsc.edu)

\begin{abstract}
Objective: Because glucocorticoids stimulate leptin release and, at least in vitro, leptin inhibits cortisol secretion, a feedback system between glucocorticoids and leptin has been proposed. However, in humans and non-human primates there are no in vivo studies to support any role for leptin in the control of the hypothalamic-pituitary-adrenal axis. In this study, we investigated the effect of leptin on (i) ACTH-stimulated secretion of cortisol in six male rhesus monkeys and (ii) basal and forskolin (FSK)-stimulated cortisol secretion by the human adrenal carcinoma cell H295R in vitro.

Design and Methods: In vivo studies: after suppression of endogenous ACTH with either dexamethasone $(n=6)$ or a corticotropin-releasing factor (CRF) antagonist (D-Phe CRF(12-41)) $(n=3), 1 \mu \mathrm{g}$ bolus of human $\mathrm{ACTH}(1-24)$ was administered to stimulate adrenal cortisol release. Blood samples were collected every $15 \mathrm{~min}$ for $3 \mathrm{~h}$. Leptin ( $1 \mathrm{mg}$ ) was infused over $4 \mathrm{~h}$, starting $1 \mathrm{~h}$ before ACTH bolus. In vitro studies: NCI-H295R cells were incubated for $6,12,24$ and $48 \mathrm{~h}$ in the absence or presence of $20 \mu \mathrm{mol} / \mathrm{l} \mathrm{FSK}$ in combination with leptin ( $100 \mathrm{ng} / \mathrm{ml}$ medium). Cortisol levels in serum and medium were measured by solid phase radioimmunoassay.

Results: Acute leptin infusion to rhesus monkeys did not change basal cortisol levels, peak cortisol levels after ACTH(1-24) or the area under the curve when compared with studies in which leptin was not given. FSK increased cortisol levels in medium at 24 and $48 \mathrm{~h}$, but leptin did not change cortisol release in either control or FSK-stimulated cells.

Conclusions: Short-term leptin infusion affected neither the cortisol response to ACTH in non-human primates in vivo nor cortisol release (basal or FSK stimulated) by H295R cells, in vitro. These data suggest that leptin may not be an acute regulator of primate adrenal cortisol secretion.
\end{abstract}

European Journal of Endocrinology 141 534-538

\section{Introduction}

Glucocorticoids participate in the control of caloric intake and adipogenesis. In patients who have elevated glucocorticoids such as in Cushing's disease, obesity or weight gain is observed in 79-95\% of the affected individuals (1). Glucocorticoids also stimulate food intake (2), synthesis and activity of the adipose tissue lipoprotein lipase (3) and adipocyte differentiation and distribution $(4,5)$. Some of these actions are in synergism with insulin $(6,7)$. Glucocorticoids also participate in epinephrine synthesis in the adrenal medulla (8) and both epinephrine and insulin influence energy metabolism.

In mouse and rat experimental models, obesity does not progress after adrenalectomy (9). In the ob/ob mouse, obesity is caused by a mutation in the gene for leptin (10), a protein that influences energy intake and expenditure (11) at both central (12) and peripheral sites $(13,14)$. Glucocorticoids stimulate the synthesis and release of leptin in rodents and humans (15-18) and reciprocally, the hyperglucocorticoidemia observed in $o b / o b$ mice is reduced with leptin administration (19). Leptin blocks HPA axis activation in restrained mice and, depending on the circumstances, can block corticotropin-releasing hormone $(\mathrm{CRH})$ release in vitro (20). Leptin also decreases basal cortisol release by bovine adrenal cells (21) and adrenocorticotropin (ACTH)-stimulated cortisol release by bovine (21) and human adrenal cells (22) in vitro. Together, these data suggest an inhibitory feedback action of leptin on the hypothalamic-pituitary-adrenal axis.

The two objectives of this study were to determine if leptin affects ACTH-stimulated secretion of cortisol in rhesus monkeys in vivo and to determine if leptin alters cortisol secretion by human adrenal carcinoma cells in vitro. 


\section{Materials and methods In vivo studies}

Six young male rhesus macaques (Macaca mulatta), $5.5-8 \mathrm{~kg}$ in weight $(3-4.5$ years old), were housed in individual cages under temperature $\left(23 \pm 2{ }^{\circ} \mathrm{C}\right)$ - and light-controlled conditions (lights on 0600-1800 h). Animals were maintained on a diet of monkey chow and fresh fruit with tap water available ad libitum. Routine daily animal care and maintenance consisted of feeding from $0700-0900 \mathrm{~h}$, cage cleaning from 0900-1000 h, and an unrestricted afternoon feeding at $1300 \mathrm{~h}$. Fresh fruit was provided three times a week. Entry into the primate room was restricted to the animal caretakers and personnel involved in the research project. All animal studies were approved by the Institutional Animal Care and Use Committee at Texas Tech University Medical Center.

Each animal experienced two studies separated by at least $48 \mathrm{~h}$. In the control study, cortisol secretion was evaluated after i.v. administration of a $1 \mu \mathrm{g}$ bolus of human ACTH(1-24) (Bachem Inc. Fine Chemicals, Torrance, CA, USA). In the experimental study, $1 \mathrm{mg}$ recombinant human leptin (R\&D Systems, Inc., Minneapolis, MN, USA) was infused for $4 \mathrm{~h}$ beginning $1 \mathrm{~h}$ before ACTH administration. We have found in other studies that this level of leptin infusion $(250 \mathrm{~g} / \mathrm{h})$ is sufficient to elevate circulating levels of leptin to the high range observed for adult macaques. The leptin bioactivity was documented by its ability to lower body weight in 6-week-old mutant obese C57BL/6J mice $(o b / o b)$ (Jackson Laboratory, Bar Harbor, ME, USA) when administered intraperitoneally for 2 days $(2 \mu \mathrm{g} / \mathrm{g} /$ $12 \mathrm{~h})$.

In six animals studies were initiated in the morning, with blood samples collected every $15 \mathrm{~min}$ between 0745 and $1100 \mathrm{~h}$. Leptin was infused between 0700 and $1100 \mathrm{~h}$ and $\mathrm{ACTH}(1-24)$ was administered immediately after the $0800 \mathrm{~h}$ sample. To achieve a homogeneous basal cortisol level at the beginning of the study, a $1 \mathrm{mg}$ i.v. bolus of dexamethasone (DXM; Sigma-Aldrich, St Louis, MO, USA) was given at midnight the night before the study.

Three additional animals were studied in the evening with blood samples collected every 15 min between 1845 and $2200 \mathrm{~h}$. Leptin was infused between 1800 and $2200 \mathrm{~h}$ and ACTH(1-24) was administered immediately after the $1900 \mathrm{~h}$ sample. The corticotropinreleasing factor (CRF) antagonist, D-Phe CRF(12-41) (Bachem Inc. Fine Chemicals) was infused $(100 \mu \mathrm{g} / \mathrm{h})$ from 1700 to $2200 \mathrm{~h}$ to suppress endogenous $\mathrm{ACTH}$ secretion.

Collection of blood samples from unrestrained animals was accomplished as previously described (23). The samples were centrifuged at the end of the study and the plasma was withdrawn and stored frozen at $20^{\circ} \mathrm{C}$ in polypropylene vials until assays were performed.

\section{In vitro studies}

Human NCI-H295R adrenal tumor cells (WE Rainey, UT Health Sciences Center, Dallas, TX, USA) (24) were grown in Dulbecco's modified Eagle's and Ham's F12 media 1:1 (v/v) (DMEM-F12) supplemented with pyridoxine $\mathrm{HCl}$, L-glutamine, and $15 \mathrm{mmol} / \mathrm{l} \mathrm{HEPES}$. Complete DMEM-F12 was prepared by adding $1 \%(\mathrm{v} / \mathrm{v})$ ITS Plus (Collaborative Biomedical Products, Bedford, MA, USA containing $6.25 \mu \mathrm{g}$ insulin $/ \mathrm{ml}, 6.25 \mu \mathrm{g}$ transferrin $/ \mathrm{ml}$, $6.25 \mu \mathrm{g}$ selenium $/ \mathrm{ml}, 1.25 \mathrm{mg}$ bovine serum albumin, and $5.35 \mu \mathrm{g}$ linoleic acid $/ \mathrm{ml}), 1 \%(\mathrm{v} / \mathrm{v})$ penicillin/ streptomycin (Gibco-BRL, Gaithersburg, MD, USA), $0.01 \%(\mathrm{v} / \mathrm{v})$ gentamicin (Sigma Chemical Company, St Louis, MO, USA) and 2\% (v/v) Ultroser G (BioSepra SA, Villeneuve la Garenne Cedex, France).

In the present studies, H295R adrenocortical cells grown in $150 \mathrm{~cm}^{2}$ flasks (Falcon, Lincoln Park, NJ, USA) were incubated at $37^{\circ} \mathrm{C}$ in a humidified atmosphere containing air/carbon dioxide (95\%/5\%, v/v). The medium was changed every 3 days and cells were subcultured with $0.25 \%(\mathrm{w} / \mathrm{v})$ trypsin every 7 days (split ratio, 1:2). To remove trypsin, the cell suspension was mixed with horse serum $(1: 2, \mathrm{v} / \mathrm{v})$, centrifuged for $10 \mathrm{~min}$ at $700 \mathrm{~g}$, then resuspended in complete DMEM-F12 and plated.

Cells used for experiments were subcultured from $60 \%$ confluent stock cultures into Nunc six-well culture plates $24 \mathrm{~h}$ before they were used. Each well was washed with $2 \mathrm{ml}$ phosphate-buffered saline (PBS) before being pre-incubated for $1 \mathrm{~h}$ in $2 \mathrm{ml}$ complete DMEM-F12. After discarding the pre-incubation medium, each well was again washed with $2 \mathrm{ml}$ PBS. Sequential 6, 12, 24 and $48 \mathrm{~h}$ experimental incubations were conducted on each set of plates with $2 \mathrm{ml}$ complete DMEM-F12 in the absence or presence of $20 \mu \mathrm{mol} / \mathrm{l}$ forskolin (FSK, Sigma Chemical Company) in combination with recombinant human leptin (100 ng/ $\mathrm{ml}$ medium). To verify that these cells were responsive to ACTH and that the steroidogenic enzymes were functional, several experiments were also conducted with ACTH(1-24) or 20 $\alpha$-dihydroxycholesterol instead of FSK (results not shown). At the end of each incubation period, the medium was removed from each well and placed in glass storage vials, each well was washed with $2 \mathrm{ml}$ PBS, and combined with the appropriate medium sample. Two milliliters of medium containing the appropriate experimental treatment was then replaced in each well and the incubation was continued. Samples in vials were frozen until assayed for cortisol. Each experimental treatment was replicated six times and the experiments were repeated four times. Leptin concentration was measured in media after $48 \mathrm{~h}$ incubation.

Assays Serum cortisol was measured in duplicate by solid phase radioimmunoassay (Diagnostic Products Corporation, Los Angeles, CA, USA). Leptin was 
measured in duplicate by radioimmunoassay (Linco Research, Inc, St Louis, MO, USA).

Data analyses The paired $t$-test was used to compare ACTH-stimulated cortisol secretion in rhesus monkeys with and without leptin infusion. The variables compared were basal cortisol levels (pre-ACTH(1-24) infusion), peak response after $\mathrm{ACTH}(1-24)$ and area under the curve. Data from the in vitro study were analyzed by repeated measures ANOVA with post hoc comparison by Fisher's method.

\section{Results}

\section{In vivo studies}

With DXM suppression of the hypothalamic-pituitaryadrenal (HPA) axis, there was no difference between groups in basal (pre-ACTH(1-24)) serum cortisol levels at $0800 \mathrm{~h}$ (mean \pm s.E.M.; $2.04 \pm 0.71 \mu \mathrm{g} / \mathrm{dl}$ control vs $1.97 \pm 0.48 \mu \mathrm{g} / \mathrm{dl}$ leptin). The cortisol peak response after $\mathrm{ACTH}(1-24)$ was achieved at $30 \mathrm{~min}$ in both groups (Fig. $1 ; 17.00 \pm 2.60 \mu \mathrm{g} / \mathrm{dl}$ control vs $15.57 \pm 2.08 \mu \mathrm{g} / \mathrm{dl}$ leptin). There were also no differences in the mean cortisol level between control and leptin-treated groups at any time point after leptin administration or in the area under the curve $(1809.7 \pm 496.47 \mu \mathrm{g} / \mathrm{dl}$ min control vs $1750.93 \pm 442.30 \mu \mathrm{g} / \mathrm{dl}$ min leptin).

In the group treated with the CRF antagonist, D-Phe CRF(12-41), there were too few animals for statistical analysis; however, the cortisol profile was similar in the absence and presence of leptin (Fig. 2). The statistical analysis of combined data (group treated with DXM and group treated with D-Phe CRF(12-41) compared with controls) indicated there were no significant effects of leptin treatment $(1712.6 \pm 555 \mu \mathrm{d} / \mathrm{dl}$ min control vs $1731.5 \pm 562.5 \mu \mathrm{g} / \mathrm{dl}$ min leptin).

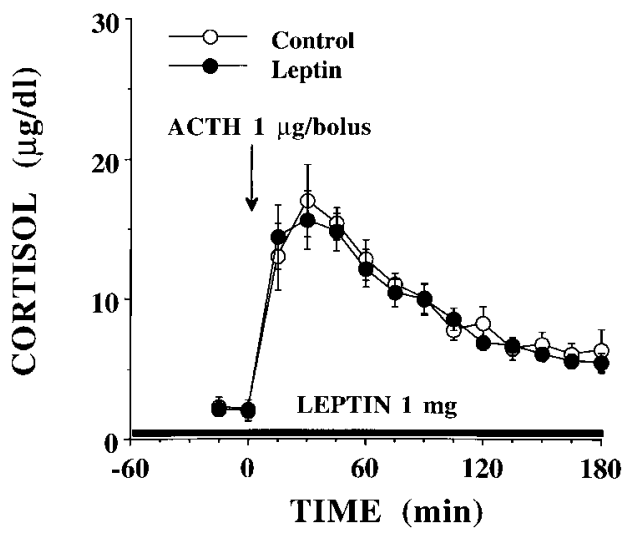

Figure 1 Cortisol levels in adult male rhesus macaques after a $1 \mu \mathrm{g}$ i.v. bolus of $\mathrm{ACTH}(1-24)$. In both the control and experimental (Leptin; $1 \mathrm{mg}$ infused over $4 \mathrm{~h}$ ) trials, the animals were treated with dexamethasone $(1 \mathrm{mg})$ at midnight before the study to suppress endogenous ACTH release.
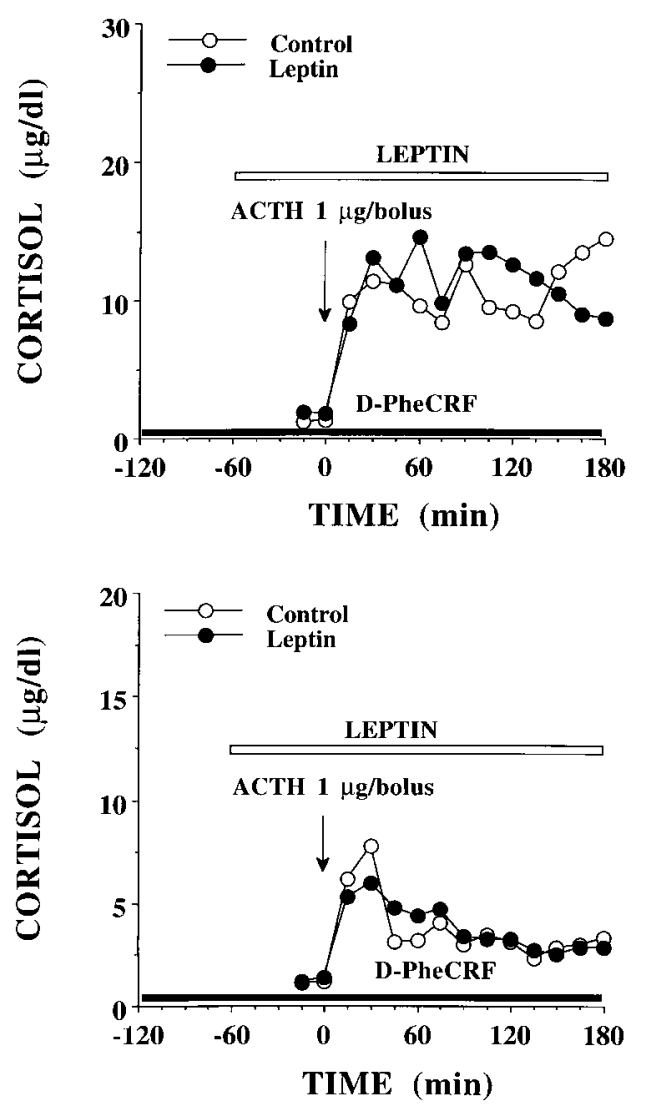

Figure 2 Cortisol levels in two adult male rhesus macaques after a $1 \mu \mathrm{g}$ i.v. bolus of $\mathrm{ACTH}(1-24)$. In both the control and experimental (Leptin; $1 \mathrm{mg}$ infused over $4 \mathrm{~h}$ ) trials, the animals were treated with a CRF receptor antagonist (D-Phe CRF(12-41); $100 \mu \mathrm{g} / \mathrm{h}$ infused over $5 \mathrm{~h}$ ) to suppress endogenous ACTH release.

\section{In vitro studies}

Cells incubated with FSK secreted significantly more cortisol than control cells at $24 \mathrm{~h}$ and $48 \mathrm{~h}$ (Fig. 3). However, the addition of leptin into the incubation medium did not change cortisol release in either control or FSK-treated cells.

\section{Discussion}

As has been reported in the human (25), $1 \mathrm{mg}$ DXM i.v. blocked ACTH-stimulated cortisol secretion after $8 \mathrm{~h}$ in the present study in male rhesus monkeys. Likewise, $1 \mu \mathrm{g} \mathrm{ACTH}(1-24)$ stimulated a robust adrenal cortisol release in male macaques. However, the maximum response was less than that observed in human subjects (26). This could be due to lower sensitivity of monkey adrenal to human ACTH or, more probably, to a loss of ACTH during the infusion as has been described recently (27).

Short-term leptin infusion had no effect on in vivo cortisol release after ACTH infusion in DXM-suppressed monkeys. Since leptin is more effective in causing 


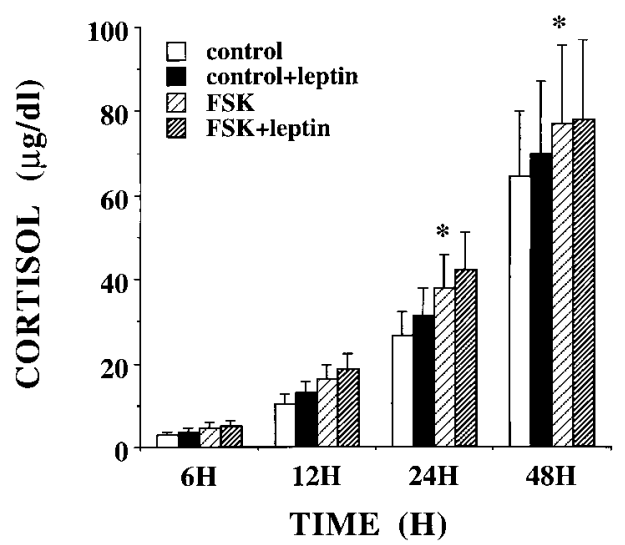

Figure 3 Cortisol release by $\mathrm{NCl}-\mathrm{H} 295$ human adrenal carcinoma cells. Forskolin (FSK) increases cortisol secretion vs control $\left({ }^{*} P<0.05\right)$ at $24 \mathrm{~h}$ and $48 \mathrm{~h}$. Leptin did not change cortisol release in either control or FSK-treated cells.

weight loss and reducing food intake in adrenalectomized rats than in intact rats and in adrenalectomized rats given DXM (28), it is possible that DXM caused leptin resistance and reduced the effect of leptin. However, in the present study, suppression of the HPA axis with a CRF antagonist, D-Phe CRF(12-41), rather than with DXM did not change the response to ACTH, indicating that the absence of a leptin effect was not due to glucocorticoid-mediated leptin resistance.

Also, leptin did not affect basal or FSK-stimulated cortisol release by human H295R adrenal tumor cells during a 48-h incubation period. The absence of a leptin effect on basal cortisol release agrees with previous studies with primary human adrenal cells $(22,29)$. However, leptin suppressed basal cortisol secretion in bovine adrenal cells (21) and contradictory leptin effects were observed during studies examining basal corticosterone secretion by rat adrenal cells. Increased basal secretion occurred with leptin treatment in one study (30) while no effect was found in another (22).

The reasons for the disparity between our results and the effects measured during previous studies are unknown. The leptin used in these experiments exhibited bioactivity and was shown to be present in the medium by RIA analysis at the end of the experiments. H295R adrenal cells were incubated with FSK instead of ACTH because we previously observed that ACTH is a weak stimulator of cortisol release in those cell (31). FSK was chosen as the stimulant to elevate H295R intracellular cAMP and cortisol secretion to avoid the suggestion that leptin effects were obscured by reduced ACTH responsiveness. If leptin does affect cortisol release from H295R cells in vitro, this effect does not involve FSK-stimulated intracellular cAMP production. It is not known whether the inhibitory action of leptin on cortisol release requires ACTH stimulation rather than FSK stimulation. Another explanation for the observed differences between normal and tumor cells could include differences in leptin receptors. However, it has recently been shown that H295R cells express the full length $\mathrm{Ob}$ receptor mRNA and protein and that leptin does not regulate tumor cell proliferation (32). Leptin receptors are also expressed in the cortex of the human adrenal (29).

In accordance with our data, there are several findings suggesting that leptin does not exert a direct effect on the adrenal cortex in vivo. In the only two reports concerning congenital human leptin deficiency $(33,34)$, the affected individuals did not have elevated plasma cortisol levels. Licinio et al. (35) found that the 24-h patterns of circulating human leptin are inverse of those for ACTH and cortisol suggesting that leptin might suppress the adrenal function. However, the diurnal rhythm of leptin is entrained to meal pattern and phase shifts in plasma leptin are apparent within hours of changing the meal pattern. These phase shifts are not correlated with cortisol levels (36).

In a previous study, we demonstrated that a 500-fold increase in serum leptin levels did not modify the daynight cortisol rhythm in fasted, pubertal male monkeys (37). In that study, however, we could not exclude a dual effect of leptin, increasing the hypothalamic $\mathrm{CRH}$ release (38) and inhibiting the adrenal cortisol release $(21,22)$.

In the present study we show that leptin affects neither the cortisol response to ACTH in male macaques in vivo, nor the in vitro response of human adrenal cells to FSK, suggesting that leptin does not regulate acute cortisol secretion in non-human primates.

\section{Acknowledgements}

We thank Qian Xu Ping, Corey Hough and Lisa Adams for excellent technical assistance. This work was supported by NIH grants HD-18591 (R L N), HL03720 (J J M), HD-17481 (D M S) and Fondo de Investigaciones Sanitarias, FIS, Spanish Ministry of Health (J L-A).

\section{References}

1 Nieman L \& Cutler GB Jr. Cushing's syndrome. In Endocrinology, edn 3, vol 2, ch 100, pp 1741-1769. Eds LJ DeGroot, M Besser, HG Burger, JL Jameson, DL Loriaux, JC Marshall, WD Odell, JT Potts Jr \& AH Rubenstein. Philadelphia, Pennsylvania: WB Saunders Company, 1995.

2 Tataranni PA, Larson DE, Snitker S, Young JB, Flatt JP \& Ravussin E. Effects of glucocorticoids on energy metabolism and food intake in humans. American Journal of Physiology 1996271 E317-E325.

3 Fried SK, Russell CD, Grauso NL \& Brolin RE. Lipoprotein lipase regulation by insulin and glucocorticoid in subcutaneous and omental adipose tissues of obese women and men. Journal of Clinical Investigation 199392 2191-2198.

4 Hauner H, Schmid P \& Pfeiffer EF. Glucocorticoids and insulin promote the differentiation of human adipocyte precursor cells into fat cells. Journal of Clinical Endocrinology and Metabolism 1987 $64832-835$. 
5 Berdanier CD. Role of glucocorticoids in the regulation of lipogenesis. FASEB Journal 19893 2179-2183.

6 Diamant S \& Shafrir E. Modulation of activity of insulindependent enzymes of lipogenesis by glucocorticoids. European Journal of Biochemistry 197553 541-546.

7 Amatruda JM, Danahy SA \& Chang CL. The effects of glucocorticoids on insulin-stimulated lipogenesis in primary cultures of rat hepatocytes. Biochemical Journal 1983212 135-141.

8 Litwack G \& Schimidt TJ. Biochemistry of hormones I: polypeptide hormones. In Textbook of Biochemistry with Clinical Correlations, pp 839-891. Ed TM Devlin. New York: Wiley-Liss Inc, 1977.

9 Bray GA \& York DA. Clinical review 90: Leptin and clinical medicine: a new piece in the puzzle of obesity. Journal of Clinica Endocrinology and Metabolism 199782 2771-2776.

10 Zhang Y, Proenca R, Maffei M, Barone M, Leopold L \& Friedman JM. Positional cloning of the mouse obese gene and its human homologue. Nature 1994372 425-432.

11 Halaas JL, Boozer C, Blair-West J, Fidahusein N, Denton DA \& Friedman JM. Physiological response to long-term peripheral and central leptin infusion in lean and obese mice. Proceedings of the National Academy of Sciences of the USA 1997948878 8883.

12 Flier JS. Leptin expression and action: new experimental paradigms. Proceedings of the National Academy of Sciences of the USA 199794 4242-4245.

13 Scarpace PJ, Matheny M, Pollock BH \& Tumer N. Leptin increases uncoupling protein expression and energy expenditure. American Journal of Physiology 1997273 E226-E230.

14 Zhou YT, Shimabukuro M, Koyama K, Lee Y, Wang MY, Trieu F et al. Induction by leptin of uncoupling protein-2 and enzymes of fatty acid oxidation. Proceedings of the National Academy of Sciences of the USA 199794 6386-6390.

15 De Vos P, Saladin R, Auwerx J \& Staels B. Induction of $o b$ gene expression by corticosteroids is accompanied by body weight loss and reduced food intake. Journal of Biological Chemistry 1995 270 15958-15961.

16 Slieker LJ, Sloop KW, Surface PL, Kriauciunas A, LaQuier F, Manetta J et al. Regulation of expression of ob mRNA and protein by glucocorticoids and cAMP. Journal of Biological Chemistry 1996 271 5301-5304

17 Larsson H \& Ahren B. Short-term dexamethasone treatment increases plasma leptin independently of changes in insulin sensitivity in healthy women. Journal of Clinical Endocrinology and Metabolism 199681 4428-4432.

18 Considine RV, Nyce MR, Kolaczynski JW, Zhang PL, Ohannesian JP, Moore JH Jr et al. Dexamethasone stimulates leptin release from human adipocytes: unexpected inhibition by insulin. Journal of Cellular Biochemistry 199765 254-258.

19 Stephens TW, Basinski M, Bristow PK, Bue-Valleskey JM, Burgett SG, Craft L et al. The role of neuropeptide Y in the antiobesity action of the obese gene product. Nature 1995377 530-532.

20 Heiman ML, Ahima RS, Craft LS, Schoner B, Stephens TW \& Flier JS. Leptin inhibition of the hypothalamic-pituitary-adrenal axis in response to stress. Endocrinology 1997138 3859-3863.

21 Bornstein SR, Uhlmann K, Haidan A, Ehrhart-Bornstein M \& Scherbaum WA. Evidence for a novel peripheral action of leptin as a metabolic signal to the adrenal gland: leptin inhibits cortisol release directly. Diabetes 199746 1235-1238.

22 Pralong FP, Roduit R, Waeber G, Castillo E, Mosimann F, Thorens $\mathrm{B}$ et al. Leptin inhibits directly glucocorticoids secretion by normal human and rat adrenal gland. Endocrinology 1998139 4264-4268.

23 Norman RL, Lindstrom SA, Bangsberg D, Ellinwood WE, Gliessman P \& Spies HG. Pulsatile secretion of luteinizing hormone during the menstrual cycle of rhesus macaques. Endocrinology 1984115 261-266.

24 Rainey WE, Bird IM, Sawetawan C, Hanley NA, McCarthy JL, McGee EA et al. Regulation of human adrenal carcinoma cell (NCI-H295) production of C19 steroids. Journal of Clinical Endocrinology and Metabolism 199377 731-737.

25 Workman RJ, Vaughn WK \& Stone WJ. Dexamethasone suppression testing in chronic renal failure: pharmacokinetics of dexamethasone and demonstration of a normal hypothalamicpituitary-adrenal axis. Journal of Clinical Endocrinology and Metabolism $198663741-746$.

26 Dickstein G, Shechner C, Nicholson WE, Rosner I, Shen-Orr Z, Adawi $\mathrm{F}$ et al. Adrenocorticotropin stimulation test: effects of basal cortisol level, time of day, and suggested new sensitive low dose test. Journal of Clinical Endocrinology and Metabolism $199172773-778$.

27 Murphy H, Livesey J, Espiner EA \& Donald RA. The low dose ACTH test - a further word of caution. Journal of Clinical Endocrinology and Metabolism 199838 712-713.

28 Zakrzewska KE, Cusin I, Sainsbury A, Rohner-Jeanrenaud F \& Jeanrenaud B. Glucocorticoids as counterregulatory hormones of leptin: toward an understanding of leptin resistance. Diabetes $199746717-719$.

29 Glasow A, Haidan A, Hilbers U, Breidert M, Gillespie J, Scherbaum WA et al. Expression of $\mathrm{Ob}$ receptor in normal human adrenals: differential regulation of adrenocortical and adrenomedullary function by leptin. Journal of Clinical Endocrinology and Metabolism $1998834459-4466$.

30 Malendowicz LK, Nussdorfer GG \& Markowska A. Effects of recombinant murine leptin on steroid secretion of dispersed rat adrenocortical cells. Journal of Steroid Biochemistry and Molecular Biology 199763 123-125.

31 Rainey WE \& Mrotek JJ. Adrenal Cortex. In Human Cell Culture, vol 1, ch 6, pp 123-135. Dordrecht, The Netherlands: Kluwer Academic Publishers, 1998.

32 Glasow A, Bornstein SR, Chrousos GP, Brown JW \& Scherbaum WA. Detection of Ob-receptor in human adrenal neoplasms and effect of leptin on adrenal cell proliferation. Hormone and Metabolic Research $199931247-251$.

33 Montague CT, Farooqi IS, Whitehead JP, Soos MA, Rau H, Wareham NJ et al. Congenital leptin deficiency is associated with severe early-onset obesity in humans. Nature 1997387 903-908.

34 Strobel A, Issad T, Camoin L, Ozata M \& Strosberg AD. A leptin missense mutation associated with hypogonadism and morbid obesity. Nature Genetics 199818 213-215.

35 Licinio J, Mantzoros C, Negrao AB, Cizza G, Wong ML, Bongiorno $\mathrm{PB}$ et al. Human leptin levels are pulsatile and inversely related to pituitary-adrenal function. Nature Medicine $19973575-579$.

36 Schoeller DA, Cella LK, Sinha MK \& Caro JF. Entrainment of the diurnal rhythm of plasma leptin to meal timing. Journal of Clinical Investigation $19971001882-1887$.

37 Lado-Abeal J. Swamy S \& Norman RL. Leptin does not affect circulating levels of $\mathrm{LH}$, testosterone or cortisol in pubertal male rhesus macaques. IV European Congress of Endocrinology. OR11-1. 1998.

38 Costa A, Poma A, Martignoni E, Nappi G, Ur E \& Grossman A. Stimulation of corticotrophin-releasing hormone release by the obese (ob) gene product, leptin, from hypothalamic explants. Neuroreport 19978 1131-1134.

Received 26 March 1999

Accepted 13 July 1999 